\title{
THE INTRODUCTION OF THE TRANSPORT SERVICE TAX AND TRANSPORT SERVICE TREASURY IN THE GRAND DUCHY OF LITHUANIA ${ }^{1}$
}

\author{
Karol Łopatecki \\ (University of Białystok)
}

ABSTRACT The article analyses actions taken and normative acts issued that formed the basis for the functioning of the transport service tax (podwoda tax) (1546-1578). The impact of Lithuanian solutions on the system introduced in the Polish Crown (1564-1565) is assessed. The tax base and characteristics of rules and collection are presented in the article. The resistance of the nobility to the introduction of this tribute is described. The resistance was much stronger than that observed for even extraordinary (one-off) taxes several dozen times higher. Reasons for the marginalisation of this tribute and the ever smaller amounts going into the Land Treasury of the Grand Duchy of Lithuania are also shown.

The article stresses that the only permanent annual tax in force in Lithuania was introduced in 1558. This state of affairs lasted until the reign of Wtadystaw IV. He donated the quarterly tax (kwarta) to the treasury as income. The potential annual revenues resulting from the introduced tax ranged between 2,700 and 4,400 zlotys, and were allocated to the transport system based on transport service provision. The Transport Service Treasury (Podwoda Treasury) was to be supervised by the treasury guardian (skarbny), together with the treasury writer (pisarz skarbowy). Both were expected to pay the calculated amounts to messengers, envoys, and other people travelling for state purposes.

KEYWORDS: transport service provision, 16th and 17th-century taxes, 16th and 17th-century finances, Grand Duchy of Lithuania, transport, 16th-century system and law.

The reign of Sigismund II Augustus in the Grand Duchy of Lithuania was the time of the greatest reform of the political system, at least until the times of Stanisław August Poniatowski. These times

${ }^{1}$ The article was written as part of the National Science Centre's research project SONATA, No 2016/23/D/HS3/o3210, entitled 'The Military Revolution as a Modernisation Factor in the Public Finance and State Organisation of the Polish-Lithuanian State in the Comparative Perspective'. 
saw the transformation of the system, laws and administration, as well as rapid social and military changes, which were largely modelled on the Crown solutions. ${ }^{2}$ The process took place under pressure from the Muscovite-Lithuanian Wars (1558-1570), which accelerated modernisation. ${ }^{3}$ It is emphasised in the literature that no significant fiscal reforms were carried out in Lithuania. Above all, the quarterly tax, introduced in the Polish Crown, was not introduced here. ${ }^{4}$ Against this background, the establishment of the Transport Service Treasury in 1558, preceded by reforms carried out from 1546, is almost completely ignored and marginalised. It should also be stressed which model solutions were first developed in the Grand Duchy of Lithuania (1551-1558), and then transferred to Polish lands $(1564-1565) \cdot{ }^{5}$ As a result, this was the first permanent tax imposed in the modern period in Lithuania. ${ }^{6}$

${ }^{2}$ Cf. A. Rachuba, Wielkie Księstwo Litewskie w systemie parlamentarnym Rzeczypospolitej w latach 1569-1763 (Warszawa, 2002), pp. 45-71; D. Szulc, 'Litewskie reformy ustrojowe lat $1564-1566$ a sprawa unii polsko-litewskiej. Podsumowanie problemu w 450-tą rocznicę wejścia w życie II Statutu Litewskiego', in: Skhidnoevropeyskiy istorichniy vicnik /East European Historical Bulletin, Vol. 3 (2017), pp. 12-21.

${ }^{3}$ A. Yanushkevich, Vyalikaye Knyastva Litoyskaye i Inflyantskaya vayna ${ }_{1558-}$ 1570 gg. managrafiya (Minsk, 2007); G. Lesmaitis, Wojsko zaciężne w Wielkim Księstwie Litewskim w końcu XV-drugiej potowie XVI wieku, trans. B. Piasecka (Warszawa, 2013).

${ }^{4}$ The quarterly tax in the Grand Duchy of Lithuania was only an extraordinary $\operatorname{tax}$ (referred to as donatywa), adopted for the first time in 1590. The attempt to create a permanent treasury in the Grand Duchy of Lithuania in the times of Sigismund III Vasa ended in failure. H. Wisner, Rzeczypospolita Wazów, t. I: Czasy Zygmunta III $i$ Wtadystawa IV (Warszawa, 2002), pp. 114-119; A. Filipczak-Kocur, Skarbowość Rzeczypospolitej 1587-1648 (Warszawa, 2006), pp. 246-249, 259-262, 344-363.

${ }^{5}$ As a rule, it is emphasised that the Grand Duchy was reformed during the reign of Sigismund II Augustus, following the example of the Polish Crown, which often led to greater transparency of solutions than it did in the Crown of the Kingdom of Poland. Researchers even point out that the Grand Duchy of Lithuania is a 'classic land of reception'. A.B. Zakrzewski, Wielkie Księstwo Litewskie (XVI-XVIII w.). Prawo ustrój - spoteczeństwo (Warszawa, 2013), pp. 38-57.

${ }^{6}$ Obviously, serebszczyzna, the tax paid in silver, existed before as a permanent tax, but it was abolished on the basis of the land privilege of 1447. From then on, it was an extraordinary tax, at least from 1507, each time adopted by the Sejm. M.K. Liubavskiy, Ocherk istorii Litovsko-Russkogo gosudarstva do Liublinskoi unii vklyuchitel'no (Moskva, 1910), pp. 200, 304-307; M.K. Liubavskiy, Litovsko-russkii Seim. Opyt po istorii uchrezhdeniia $v$ sviazi s vnutrennim stroiem i vneshnei zhizn'iu gosudarstva (Moskva, 1900), pp. 97-104; W. Kamieniecki, 'Chorążowie w parlamentaryzmie litewskim przed unią lubelską, in: Antemurale, Vol. 9 (1965), p. 188. 
No other tax was introduced until the quarterly tax at the end of the reign of Władysław IV.7

In the article, I analyse normative acts that formed the basis for the functioning of the transport service tax $(1547-1567)$. I attempt to assess the impact of Lithuanian solutions on the system introduced in the Polish Crown. I also try to evaluate the revenue resulting from this tribute, its collection capacity, and collection characteristics. I indicate the reasons for the marginalisation of this tribute, and the increasingly smaller amounts paid to the Land Treasury of the Grand Duchy of Lithuania. Nevertheless, I omit the extremely important but extensive issues of the costs of fulfilling transport service provision duties, the manner of their collection, and, in general, the functioning of the information transfer system, which require separate analysis. ${ }^{8}$ Neither do I deal with the duty, or rather the extortion, of transport service provision by state troops. ${ }^{9}$

In the literature, the issue of the reform of the Transport Service Treasury is discussed primarily in historical and legal terms. Interestingly enough, there were two separate views of the Lithuanian and Polish Transport Service Treasury, and no consideration given to common features and possible differences. ${ }^{10}$ Regarding the practical

${ }^{7} \mathrm{H}$. Wisner, Rzeczpospolita Wazów, t. II: Wojsko Wielkiego Księstwa Litewskiego, dyplomacja, varia (Warszawa, 2004), pp. 75-76; H. Wisner, Rzeczpospolita Wazów, t. III: Stawne Państwo Wielkie Księstwo Litewskie (Warszawa, 2008), pp. 227-228.

${ }^{8}$ See:J. Jurkiewicz, 'Powinności podwodowe włościan w Wielkim Księstwie Litewskim (XVI-XVIII w.). Z zagadnień ich terminologii i klasyfikacji', in: Istorijos akiračiai. Skiriama profesoriaus habilituoto daktaro Antano Tylos 75-mečiui, ed. E. Rimša (Vilnius, 2004), pp. 101-126; J. Jurkiewicz, '„Podróże” chłopów Wielkiego Księstwa Litewskiego w XVI-XVIII w. (z zagadnień powinności transportowych włościan)', in: „Młodsza Europa" od średniowiecza do wspótczesności. Prace ofiarowane Profesor Marii Barbarze Piechowiak Topolskiej w siedemdziesiąta rocznicę urodzin, ed. J. Jurkiewicz, R.M. Józefiak, W. Strzyżewski (Zielona Góra, 2008), pp. 301-320.

${ }^{9}$ This issue has been the subject of numerous analytical works. For example: T. Srogosz, 'Ekonomiczne i społeczne następstwa przemarszów oraz stacjonowania wojsk własnych na terenie województw łęczyckiego i sieradzkiego oraz ziemi wieluńskiej w XVII wieku', in: Acta Universitatis Lodziensis. Folia Historica 37 (Łódź, 199o), pp. 3-33; U. Augustyniak, W stużbie hetmana i Rzeczypospolitej. Klientela wojskowa Krzysztofa Radziwitta (1585-1640) (Warszawa, 2004), pp. 69, 106, 109ff.

${ }^{10}$ First of all, the following work should be mentioned: S. Wysłouch, Postugi komunikacyjne w miastach W. Ks. Litewskiego na prawie magdeburskiem do połowy 
implementation of the tax in Polish Crown lands, the work by Adolf Pawiński is still of crucial importance. Unfortunately, there is no similar analysis from the perspective of the Grand Duchy of Lithuania." Short, mostly one or two-sentence mentions, are made by researchers dealing with the history of Polish-Lithuanian postal services. All the key studies appeared in the 19th or the first half of the 2oth century, which demonstrates little interest in the problem. In contemporary works, even in extensive monographs on the economy and finances of the 16th and 17th centuries, the issue of the transport service tax or treasury in Lithuania is non-existent, or at best only mentioned perfunctorily. Meanwhile, the research problem is by no means of secondary importance. Providing a special treasury for the efficient transport and transfer of goods and people for the needs of the state is of paramount importance. It is an essential element of the modernisation of the states governed by Sigismund II Augustus. This is an instance of an attempt to move from a royal domain state to money obtained by way of taxation. ${ }^{12}$

Before reforms were launched in Lithuania to introduce a transport service tax and a Transport Service Treasury, the progressive decline of the transport service provision system could be seen. Even in the days of Grand Duke Vytautas rule, the obligation of transport service provision applied to all inhabitants to a very wide extent. ${ }^{13}$ Exemption from this obligation, in relation to the economic needs of the estates and castles of the grand duchy, was brought about only by the land privilege of Casimir IV from 1447.

XVI w. (Vilnius, 1936). Unfortunately, the author brings his deliberations to an end at a point that is crucial for this article. This is because he is interested in transport service provision from before the reforms of the mid-16th century. From the perspective of the Polish Crown, the following article continues to play a key role: S. Kutrzeba, 'Podwody miast polskich do roku 1564', in: Przewodnik Naukowy i Literacki 27(5) (Lwów, 1900), pp. 495-509.

${ }^{11}$ A. Pawiński, Skarbowość w Polsce i jej dzieje za Stefana Batorego (Warszawa, 1881), pp. 112-117.

${ }^{12}$ E.L. Petersen, 'From domain state to tax state', in: Scandinavian Economic History Review, Vol. 23, No 2 (1975), pp. 116-148.

${ }^{13}$ S. Polechow, 'Itinerarium wielkiego księcia litewskiego Witolda: 4/5 sierpnia 1392 - 27 października 143o', in: Rocznik Lituanistyczny, Vol. 5 (2019), pp. 38-39, the broad subject literature is also mentioned there (footnote 177). 
These regulations were repeated in relation to Smolensk (1506) and Kiev (1507) lands. On the other hand, the envoys and messengers of the grand duchy were obliged to pay the transport service tax at the usual rate. These very general standards were repeated in 1529 , 1547 and 1566. In addition to the rule described above, from the second half of the $15^{\text {th }}$ century, there was a tendency for the grand duke to exempt boyars, magnates and cities from transport service provision. The Kiev region was the first to obtain full exemption for the nobility and clergy from this obligation, in 1529. These trends led to increased obligations imposed on settlements that had not obtained exemption. ${ }^{14}$ The growing phenomenon prompted other entities to apply for exemption, and as a consequence, the entire transport service provision system was dismantled. The process was all the more dangerous given the war with Muscovy and the need to ensure permanent contact between border areas and the centre of the state..$^{15}$ Therefore, at the end of the first half of the 16th century, Sigismund II Augustus undertook to carry out vital fiscal reform. It consisted of three stages:

1) the abolition (probably in 1546) of privileges and letters of merit exempting entities from road duties;

2) the introduction in 1551 of the transport service tax for landowners;

3) the adoption in $155^{8}$ of a uniform transport service tax in cities, and the clarification of the manner in which it was collected and the rules for transport service provision. ${ }^{16}$

At the Vilnius Sejm in January 1547 , the nobility and magnates submitted through the councillors a request not to violate privileges

${ }^{14}$ The municipal authorities pointed out that the existing situation led to the escape of the townspeople who wanted to avoid transport service provision duties (this concerned, among others, Kamieniec Litewski or Vawkavysk). S. Wysłouch, Postugi..., pp. 14-26, 47. Cf. A.B. Zakrzewski, Wielkie Księstwo...; K. Pułaski, 'Powinności wojskowe mieszczan w dawnych miastach na Rusi', in: Biblioteka Warszawska, Vol. 4 (1872), pp. 263-264.

${ }^{15} \mathrm{H}$. Łowmiański ('Posługi komunikacyjne w miastach W. Ks. Litewskiego na prawie magdeburskiem do połowy XVI w., S. Wysłouch, Wilno 1936', in: Ateneum Wileńskie, Vol. 12 (1937), p. 6o1) drew attention to the correlation between wars waged by the Grand Duchy of Lithuania and transport service provision reforms.

${ }^{16}$ Russkaia istoricheskaia biblioteka, t. XXX: Litovskaia metrika, Otd. 1-2, chap. 3 (Knigi publichnykh del, t.1), ed. I.I. Lappo (Yur'iev, 1914), pp. 161-162, 218-219, 592-599. 
(vyslug) obtained in the form of 'letters of exemption'. ${ }^{17}$ By this term, contemporaries understood a broad catalogue of exemptions, including transport service provision, but also castle works, participation in the construction and maintenance of bridges and roads, offering accommodation, etc. However, the ruler did not change his mind, and at the same time announced that these issues would be sorted out in the future. ${ }^{18}$ The origins of this state of affairs can be found in Article 22, Chapter 1, of the First Lithuanian Statute. This regulation repeats the privilege of exemption from commercial transport service provision; however, in the second part, it retains in its entirety the custom of, among others, providing transport services to messengers, wherever the obligation used to apply. ${ }^{19}$ Sigismund II Augustus decided to use this regulation, and at the same time, eliminated any individual exemptions.

The second stage of the reform took place in the Vilnius Sejm in 1551. The assembly was largely concerned with the issue of the military defence of the Grand Duchy of Lithuania. ${ }^{20}$ This was when the law on transport service provision was also passed, so that messengers and envoys could easily deliver information and documents for the needs of the state. Transport service provision duty was restored in respect to the entire population that had once been obliged to render transport services. Thus, transport

\footnotetext{
${ }^{17}$ Exemptions were granted to entire towns as well as individual inhabitants; they were also awarded to independent dukes, boyars, courtiers and princes (kniaź). In addition, it was customary to surrender to the power of the mighty in order to evade transport service provision duty. S. Wysłouch, Postugi..., pp. 127-155.

${ }^{18}$ Russkaia istoricheskaia biblioteka, t.XXX, Otd.1-2, chap. 3, No 3, art. 23, pp.161-162; Akty, otnosiashchiiesia k istorii Zapadnoi Rossii, t. III: 1554-1587 (St Petersburg, 1848), p. 14; S. Wysłouch, Postugi..., p. 22.

${ }^{19}$ I khochem pri tselosti zostaviti zdavna zvychayne obychai podymovan'ya statsei na stanekh z starodavna zvychaynykh, mosty starye popravliati i novye na starykh mestekh budovati, zamki starye popravliati i tam zhe na tykh starykh mestekh del'nitsy svoi znovu budovati, mostov novykh budovan'ia i starykh dorog naprovovan'ia, i pod gontsy nashi podvod davania, gde z starodavna davainy sut' (Pirmasis Lietuvos statutas. Tekstai senaja baltarusiu, lotynu ir senaja lenku kalbomis, parengė S. Lazutka et al., t. II, dalis 1 (Vilnius, 1991), p. 84, art. 22 (chap. I)).

${ }^{20}$ Russkaia istoricheskaia biblioteka, t. XXX, Otd. 1-2, chap. 3, doc. 8, pp. 218-219; Akty, otnosiashchiesia kistorii Zapadnoi Rossii, doc. 5, p. 45. At that time, serebszczyzna was adopted for three years: 'Prilozheniia', in: M.K. Liubavskii, Litovsko-russkii Seim..., p. 72 .
} 
services were to be provided not only by state property, but also by private owners and tenants who received land from the rulers and who had previously been burdened with this service. At the same time, a standard was introduced to allow for the exemption from transport service provision in exchange for the payment of a special tax. ${ }^{21}$ The amount of the obligation was set at six groszy for transport service provision per year ${ }^{22}$. This amount had to be paid in two half-yearly instalments. With these funds, a separate treasury was to be set up, from which the ruler was able to pay envoys and messengers.

While the first regulation gained the approval of the Sejm, the second one aroused great controversy, and some of the attendees went home, unwilling to consent to it. But Sigismund II Augustus decided that the regulation was approved by most members of the nobility. Still, the case was by no means closed in the face of further resistance from the political elite. I would like to emphasise that this was all about a permanent annual tax paid not only by towns but also by landowners. It is no wonder, therefore, that the ruler had to justify the law in broader terms on 26 December $155^{2 .}{ }^{23}$ In a letter addressed to the ruling class of the state, he stressed the possibility of paying fees to powiats (into the hands of the ensigns) or towards leases (to governors or leaseholders). In his opinion, the lack of tax revenue resulted from the negligence of the ensigns, so he demanded the implementation of the adopted regulations. ${ }^{24} \mathrm{He}$ underlined again and again that the letters of exemption did not have legal force if they

${ }^{21}$ This solution was analogous to the fee for exemption from compulsory military service (pokoniewszczyzna). G. Lesmaitis, Wojsko..., pp. 139-140.

${ }^{22}$ The term 'transport service' should be understood as 'service' burdened with transport service provision duty. This unit of measurement was imprecise, it could be an area of about 1-3 wtókas, i.e. an area equivalent to about 18 ha, which consisted of two 'smokes', i.e. two homesteads. In the levy-en-masse (pospolite ruszenie), one horse handled between five and 11 services (depending on the Sejm resolution). K. Łopatecki, Organizacja, prawo i dyscyplina w polskim i litewskim pospolitym ruszeniu (do połowy XVII wieku) (Białystok, 2018), p. 15 o.

${ }^{23}$ 'Prilozheniia', in: M.K. Liubavskii, Litovsko-russkii Seim..., pp. 72-74.

${ }^{24}$ The ensigns were responsible for collecting taxes. A. Zakrzewski, 'Chorążowie nie tylko w parlamentaryzmie litewskim', Hortus bellicus. Studia z dziejów wojskowości nowożytnej. Prace ofiarowane Profesorowi Mirostawowi Nagielskiemu, 
concerned state (land) obligations and defence issues. Former privileges were applicable insofar as they included exemptions or reliefs relating to the grand duke's benefits. This source was all the more important, as it presented the concept of separating the private treasury of the grand duke (court) from the public (land) treasury. ${ }^{25}$ The latter was intended to support the state and enable its smooth functioning. In the light of Sigismund II Augustus' arguments, no ruler was legally empowered to grant privileges in respect of the land treasury. ${ }^{26}$

The year $155^{2}$ did not put an end to the controversy. Once again, the nobility who gathered at the Sejm in 1554 asked the grand duke to abolish the restored transport service provision burdens. It was argued that no additional clauses concerning the fulfilment of tributes to the ruler were included in land grants. Sigismund II Augustus once again stressed that transport services were nationwide by their nature, and did not constitute his personal income. They were a public duty, and therefore could not be relieved by any ruler. All those who were obliged to provide transport services and accommodation, regardless of individual exemptions, were obliged to fulfil their duty or pay tax. The king emphasised that people (settlements) who had never been obliged to provide transport services were not obliged to provide them. ${ }^{27}$

ed. K. Bobiatyński, P. Gawron, K. Kossarzecki, P. Kroll, D. Milewski (Warszawa, 2017), p. 74; W. Kamieniecki, 'Chorążowie...', pp. 188-19o.

${ }^{25}$ Formally, both treasuries were separated in 1589 ; nevertheless, the separation of the Land Treasury began much earlier, which is associated with the strengthening of the function of the land treasurer, first of all Iwan Hornostaj. Ostaffi Wołłowicz significantly expanded his competences, being able to make financial decisions on his own (1561). M.K. Liubavskii, Litovsko-russkii Seim..., pp. 114ff.; H. Wisner, Rzeczpospolita Wazów..., t. I, pp. 75-76; H. Wisner, Rzeczpospolita Wazów..., t. III, pp. 204ff. Cf. A. Tyla, Lietuva ir Livonija XVI a. pabaigoje - XVII a. pradžioje (Vilnius, 1986); A. Tyla, 'Lietuvos rūmų iždas: pajamų šaltiniai ir jų panaudojimas (XVI a. pab. - XVII a.)', in: Lietuvos istorijos metraštis, 1995 (1996), pp. 29-48 (in particular p. 39); A. Filipczak-Kocur, Skarbowość..., pp. 221-332.

${ }^{26}$ Different reasoning: S. Wysłouch, Postugi..., p. 135.

${ }^{27}$ Russkaia istoricheskaia biblioteka, t. XXX, Otd. 1-2, chap. 3, doc. 9, pp. 235236: "pod"vody i statsei ne est" pozhitok" skar"bu ego krolev"skei milosti, ale osoblivyi pozhitok" i potreba rechi pospolitoe, shto nikomu ne mozhe byti otdano' (Cf. S. Wysłouch, Postugi..., p. 23). 
The situation in the period between 1542 and 1558 was not entirely clear. The maintenance of alternative options for the payment or fulfilment of transport service provision duty invited abuse. It was not entirely clear which settlements were obliged to provide transport services and which ones were not. After all, Sigismund II Augustus' reasoning may have seemed strange, given that freedoms similar to those advocated by the Lithuanian nobility had existed in the Crown since the end of the 14 th century. ${ }^{28}$

The transition period was closed by the proclamation by the grand duke (kniaź) issued together with councillors in Krasnystaw on 20 June $1558{ }^{29}$ It should be noted that it was not published in the form of a constitution. The subject concerned mainly the estates of towns and dukes (hospodars), and with regard to landed property, the act was only a repetition or a slight detailing of the solutions adopted in 1551. I present below the characteristics of this document, with a view to introducing a new transport service tax and transport service treasury.

When justifying the issue of the new regulation, the grand duke emphasised the need to maintain a good connection with the borderlands. No less important, although articulated directly only in the transport service provision reform carried out in the Crown, was the equalisation of the burden of transport service provision. ${ }^{30}$ At the beginning of the act, the ruler stressed that the proclamation applied to all settlements except privileged ones, those that had always been free of transport service provision duty. This meant that the tax was paid by all towns, not just royal ones. Even

\footnotetext{
${ }^{28}$ S. Krzyżanowski, 'Podwody kazimierskie 1407-1432, in: Archiwum Komisyi Historii, Vol. 11 (Kraków, 1912), p. 393.

29 'Postanovleniia velikago kniazia Sigizmunda Avgusta ob otpravlenii podvodnoy povinnosti', Krasnystaw 20 VI 1558, in: Russkaia istoricheskaia biblioteka, t. XXX, Otd. 1-2, chap. 3, pp. 592-599. No place of issue of the document, location determined on the basis of: A. Gąsiorowski, 'Itinerarium dwu ostatnich Jagiellonów', in: Studia Historyczne, Vol. 16, No 2 (1973), p. 270.

$3^{0}$ 'Uniwersał podwodny warszawski', 28 III 1564 Warszawa, in: Volumina Constitutionum, t. II: 1550-16og, Vol. 1: 1550-1585, ed. S. Grodziski, I. Dwornicka, W. Uruszczak (Warszawa, 2005), p. 144.
} 
privileged towns, which were never obliged to provide transport services, had to pay tax for the suburbs. ${ }^{31}$ A regular annual tax obligation was imposed on all those required to provide transport services. Based on the financial law terminology, it was actually a fee, as the introduction of the tax rate was associated with the widespread abolition of free transport service provision..$^{32}$ It seems, however, that this judgment would be of an ahistorical nature, not taking into account the specificity of the reform consisting in the transition from a domain-based state to a money-based state.

The transport service tax was regulated as follows. All the inhabitants of the towns and suburbs were to pay two groszy per house. Urban land to the amount of three groszy per wtóka was also taxed (a morga required a fee of four coins, an area of about 20 square metres [pręt kwadratowy] in the garden one coin, and a town farm required a payment of six groszy per wtóka), while the gardener was obliged to pay two groszy. In areas where no measurements in wtókas were carried out (on Ruthenian land) 'smoke' (two groszy) and beekeeping trees (three groszy per tree climbing spike) were taxed, as well as gardens (one groszy); other people had to pay half a groszy each. ${ }^{33}$ Specific fees were also introduced for craftsmen and merchants. ${ }^{34}$ The

\footnotetext{
${ }^{31}$ This was the case for towns completely exempt from the transport service provision obligation: Vilnius (1451), Trakai (1522), Kiev (1522) and Turzyska (1522); S. Wysłouch, Postugi..., pp. 129-130. As early as 1558, these towns received taxexemption privileges from the ruler, with an emphasis on the need for people not subject to Magdeburg Law to fulfil their transport service provision duties (the emphasis was placed on the population subject to Church and noble authority); these people were expected to keep their horses ready to provide transport services. Archiwum Gtówne Akt Dawnych, Archiwum Radziwiłłów (henceforth - AGAD AR), II, ref. 3306, p. 1.

${ }^{32} \mathrm{P}$. Felis, Elementy teorii i praktyki podatków majątkowych. Poszukiwanie tadu w opodatkowaniu nieruchomości w Polsce z perspektywy przedsiębiorców oraz jednostek samorzadu terytorialnego (Warszawa, 2012), pp. 21-23.

${ }^{33}$ The fees may have differed in detail, e.g. the landowners of Bracław and Winnica were expected to pay three groszy per 'smoke', and in places where bees were kept in hives, one groszy was to be paid for every ten bee hives. 'Nauka panu Yanu Volchkovichu', Wilno 28 XI 156o, in: Arkhiv Iugo-zapadnoi Rossii, chap. 8, t. 5: Akty ob ukrainskoi administratsii v XVI-XVII v.v. (Kiev, 1907), pp. 130-131.

${ }^{34}$ The fees depended on the type of craft or trade. Cf. H. Łowmiański, Studia nad dziejami Wielkiego Księstwa Litewskiego (Poznań, 1983), p. 525. In the supplementary
} 
burdens on landed property were renewed (six groszy each for the service). ${ }^{35}$

The taxes were to be paid to the manor house or the hospodar's castle (to the governor-leaseholder), and in the powiats of the nobility they could be handed over to the grand duke's official. ${ }^{36}$ Following the $155^{1}$ Constitution, this tax was to be paid in two equal instalments. Then, within two weeks, each collector was to hand over the money to the grand duke's treasury. In practice, however, this income was kept for many years by starosts. ${ }^{37}$

The only group of people exempted from the transport service tax consisted of village heads (wójt) (mayors), who were responsible for tax selection, and were financially liable for any delays and errors. A special category of localities was also introduced which, although exempt from the obligation to pay the transport service tax, had to keep horses for transport service provision. In later years, a process of establishing such a group of localities can be observed. ${ }^{3}$

When looking for models providing a basis for the solution introduced in 1558 , bottom-up initiatives taking shape in Lithuania

document to the act in question, the grand duke exempted foreign merchants who did not have a house in the Grand Duchy of Lithuania because they paid the toll. Russkaia istoricheskaia biblioteka, t. XXX, Otd. 1-2, chap. 3, p. 599.

${ }^{35}$ Examples of the recorded transport service tax on landed property: 'Inventar' zamka Orshanskago', 12 VII 156o, in: Dokumenty Moskovskago arkhiva Ministerstva iustitsii (Moskva, 1897), p. 127; 'Opisashe starostva Beresteyskago, 1566 goda', in: Dokumenty..., p. 236. Where the transport service tax had already been introduced, the leaseholders and the governors attempted to choose two parallel obligations. The grand duke usually removed the double duties by specifying their duties at six groszy for the service. Metryka Vyalikaga knyastva Litoyskaga. Kniga 42 (1556-1562): Kniga zapisay̆ $N^{o} 42$ (kopiya kantsa XVI st.), ed. V.C. Myanzhynski (Minsk, 2015), pp. 99-100 (doc. 79).

${ }^{36}$ At least in the first period of the existence of transport service provision (in the 155 os), this tax was collected by ensigns. 'Prilozheniya', in: M.K. Liubavskii, Litovskorusskii Seim..., p. 73 .

${ }^{37}$ Lietuvos Metrika kn. 564 (1553-1567), Viešujų reikalų knyga 7, ed. A. Baliulis (Vilnius, 1996), doc. 106, p. 109; Lietuvos Metrika (1566-1574), knyga nr. 51, ed. A. Baliulis, R. Ragauskienè, A. Ragauskas (Vilnius, 200o), p. 195 (doc. 139); Metryka Vyalikaga knyastva Litoy̆skaga. Kniga 42..., pp. 99-100 (doc. 79).

${ }^{38}$ Metryka Vyalikaga knyastva Litoy̆skaga: Kniga 44: Kniga Zapisay̆ 44 (1559-1566), ed. A. I. Grusha (Minsk, 2001), No 40 (p. 50). The suburbs of Kiev, for instance, also benefited from exemption: AGAD AR, II, ref. 3306, p. 1. 
can be indicated. The first half of the 16th century saw the growing popularity of agreements entered into between townspeople and starosts (or commune mayors) for transport service provision. The former committed themselves to annual taxation in money, possibly in grain, while the latter guaranteed the purchase of horses and transport service provision. ${ }^{39}$ On the other hand, on landed property there was a process of converting the free transport service obligation into permanent monetary fees. This phenomenon existed, among others, on the Lubecz estate (starosty). After the death of Olbracht Gasztołd (1539), an inventory was carried out on the property, in which it was noted that the duty of transport service provision was converted into an annual fee of six groszy for the service. ${ }^{40}$

A very important issue was the ruler's declaration that a special transport service treasury would be separated. This term is to be understood as a special transport service tax fund to be managed by certain people at the grand duke's court. ${ }^{41}$ The role of this institution was crucial for the efficient functioning of the state, as the existing state transport based on free transport service provision was replaced by fees. Therefore, the transport service tax fund always had to have cash to enable enforcement officers, envoys, courtiers and royal messengers to perform their duties. ${ }^{42} \mathrm{~A}$ special situation concerned sending envoys from the borderlands to the court; then similar money was to be offered by voivodes, starosts or leaseholders. When the messengers finally arrived at the court, the money was to be returned to them. ${ }^{43}$

${ }^{39}$ Lietuvos Metrika. Knyga nr. 47 (1565-1567). Užrašymu knyga 47, ed. E. Deveikytė, G. Lesmaitis (Vilnius, 2018), doc. 6 (pp. 22-23), 100 (pp. 82-83); S. Wysłouch, Postugi..., pp. $44-46$.

${ }^{40}$ Metryka Vyalikaga knyastva Litoy̆skaga. Kniga 42..., pp. 99-100 (doc. 79).

${ }^{41}$ I budut oznaimeny osoby pevnye pri dvore i svarbe iego mvlostv gospodar svom, takovye, khto tye penezi na podvody rozdavati mayet z skarby'. 'Postanovleniia velikago kniazia Sigizmunda Avgusta ob otpravlenii podvodnoi povinnosti', Krasnystaw 20 VI 1558, in: Russkaia istoricheskaia biblioteka, t. XXX, Otd. 1-2, chap. 3, p. 597.

${ }^{42}$ Separate analytical studies are necessary on the prices of hiring horses, carriages and guides, and the way transport service duties were carried out.

43 'Postanovleniia velikago kniazia Sigizmunda Avgusta ob otpravlenii podvodnoi povinnosti', Krasnystaw 20 VI 1558, in: Russkaia istoricheskaia biblioteka, t. XXX, Otd. 1-2, chap. 3, pp. 592-599. 
The Transport Service Treasury, as announced, was separated, at least during the reign of Sigismund II Augustus. This is evidenced by the settlement of the treasurer Ostafi Wołłowicz for the period 1561 to $1566 .{ }^{44}$ Special expenditure on transport service provision and various grand duke and hetman messengers was noted at the end of the report. The expenditure was clearly separated from the entire settlement, emphasising that it was under the general supervision of the land treasurer (and therefore it was money available to the Land Treasury). Ivan Semenowicz Zarecki (Zarzecki), the mayor of Vilnius and Lithuanian treasury guardian, was responsible for the expenditure. ${ }^{45}$ The second person was notarius magnus Lithuaniae, Michał Bohdanowicz Haraburda. Both were responsible for spending transport service provision funds, and keeping accurate records of expenditure (shafovan'e podvod' $v^{\prime}$ sprave svoiei mel' shto vse dostatochne $v$ reiestrakh' skarbnogo $i$ Garaburdinykh'). This information is important, as it coincides with the provisions of the $155^{8}$ reform. The settlement confirms that transport service provision funds became part of the Land Treasury, unlike the Crown, where they were part of the Court Treasury. ${ }^{46}$

The two-person cooperation between the treasury guardian and the treasury writer in disposing of transport service funds continued for decades. ${ }^{47}$ This is indicated by the tax ordinance issued on 10 September 1568 and repeated in 16o7. In the light of this legal

44 'Kvitantsiia Podkan'tslerogo marshalka dvornogo Volovicha zo vsego chasu podskarbstva iego mlti i sovseie sumy na prikhode i raskhode polozhonoie i okazanoie vechnym' chasom', Rossiiskii gosudarstvennyi arkhiv drevnikh aktov (henceforth RGADA), f. 389 , No 48, f. $28-228 v$.

${ }^{45}$ For more about the office of the treasury guardian, i.e. the deputy of the land treasurer: A. Filipczak-Kocur, Skarbowość..., pp. 233-238.

${ }^{46}$ The permanence of this position in the 17 th-century Treasury is confirmed by: 'The amount of royal money, received and spent'. AGAD AR, II, ref. 1211, p. 2. The king received the rest of the tax money from the Land Treasury. There was an annotation: 'Income from Mr Treasury Guardian from the remaining debt [Retenta] and collection of transport service money.' In the Crown, on the other hand, being part of the Court Treasury was directly confirmed by the Constitution of 159o. 'Rationes stołu Krola Iego Miłości', in: Volumina Constitutionum, t. II: 1550-16o9, Vol. 2: 1587-1609, ed. S. Grodziski (Warszawa, 2008), p. 148.

${ }^{47}$ Interestingly, in the 18th century, the treasury guardian Jan Odachowski became the administrator of the post, whose income was the former transport service tax. Cf. Urzędnicy centralni i dygnitarze Wielkiego Księstwa Litewskiego XIV - XVIII wieku. Spisy, ed. H. Lulewicz, A. Rachuba (Kórnik, 1994), pp. 131, 182. 
act, revenue and expenditure records were to be kept in duplicate by the two above-mentioned officials. The disposal of money itself rested with the treasury guardian, according to detailed rules set out by the king or the treasurer. In military matters in particular, the disposal was to take place with the common knowledge of the treasury guardian and the writer. ${ }^{48} \mathrm{~A}$ similar situation is likely to have applied to the collection of the transport service tax and its disbursement for transport purposes.

Of course, the regulations announced in 1558 were discussed at the next Sejm, which took place in Vilnius in 1559. Once again, Sigismund II Augustus noted that the transport service tax also applied to the nobility and the clergy. The tax base should cover services that used to be burdened with transport service provision in the past. Landowners were not to be subject to regulations intended for towns, except where private settlements were obliged to keep horses for transport service provision. In these cases, they were to pay like townspeople or peasants. The king demanded the payment of the first instalment of three groszy for the service from all those obliged to pay, under the threat of providing transport services against no fee. Sigismund II Augustus warned that (na Svetyi Mar'tin' prishlogo sviata ne ot'dast,' roskazhet' to iego krolev'skaia milost' $z$ dets'kovan'iem' ot'pravovati na takovykh' liudekh').49 The announcement of dzieckowanie meant the application of justice with the help of special officials called $d z i e c c y$. They were allowed to detain defendants and take them to court, possibly serve statements of claim or issue judgments, and sometimes enforce them. The nobility had a very negative opinion of the participation of $d z i e c c y$ at any stage of the proceedings, considering that they were characterised by a high degree of ruthlessness and direct dependence on the ruler. The announcement of $d$ zieckowanie should also be understood as the possibility of financial sanctions..$^{5^{\circ}}$ Confirmation of this threat can be found in 1562 when the ruler sent

${ }^{48}$ AGAD AR, II, ref. 59, pp. 1-3.

${ }^{49}$ Russkaia istoricheskaia biblioteka, t. XXX, Otd. 1-2, chap. 3, pp. 276-278; Cf. S. Wysłouch, Postugi..., pp. 23-24.

${ }^{5 \circ} \mathrm{O}$. Kanecki, 'Recepcja urzędu dzieckiego z Rusi do struktur państwowych Wielkiego Księstwa Litewskiego', Pogranicza w historii prawa i myśli polityczno-prawnej, ed. D. Szpoper, P. Dąbrowski (Gdańsk-Olsztyn, 2017), pp. 269-276. 
a letter to ten leaseholders who retained transport service funds from the towns. In the letter, Sigismund II Augustus demanded the issue of tax arrears under the threat of sending a courtier who, by means of $d z i e c k o w a n i e$, was to collect the money. ${ }^{51}$

By the 156 os, the tax was established and no longer so controversial. $^{5^{2}}$ The Sejm only mentioned it twice. First, in 1563 , the Kiev nobility demanded confirmation of the former privileges, because from 1529, it was exempt from the payment of transport service tax to the voivode of Kiev. Sigismund II Augustus agreed to this request, but stressed that providing transport services and accommodation was obligatory when the voivode of Kiev personally arrived in or left Kiev. ${ }^{53}$ The issue was raised again at the Grodno Sejm in 1567. It was then decided to increase tax discipline, reminding owners of their obligation to pay the transport service tax; in the event of arrears, they were to be taken before the court of the grand duke and the councillors. ${ }^{54}$

More attention should be paid to the mutual relations between Lithuanian and Polish solutions. In the Crown, Sigismund II Augustus published the 1564 proclamation, where he explicitly noted that he had previously announced a similar act in the Grand Duchy of Lithuania. ${ }^{55}$ This comparison was not made earlier; it was merely stated that the Crown act was based on $^{56}$ or was a literal copy

${ }^{51}$ Lietuvos Metrika kn. 564 (1553-1567)..., doc. 106, p. 109.

${ }^{52}$ The Second Lithuanian Statute (1566) confirmed the previous solutions: a ban on commercial transport service provision and an order of transport service provision to the benefit of envoys, messengers and the grand duke. 'Statut litewski drugiej redakcyi (1566)', Pomnik prawa litewskiego z XVI wieku, ed. F. Piekosiński (Kraków, 19oo), chap. III, art. 24, pp. 58-59.

${ }^{53}$ Dokumenty Moskovskago arkhiva..., p. 148; S. Wysłouch, Postugi..., p. 47 (from 1522, the voivodes of Vilnius received 100 kopas groszy a year, or equivalent, for the obligation to provide transport services to Tartar missions).

${ }^{54}$ Russkaia istoricheskaia biblioteka, t. XXX, Otd. 1-2, chap. 3, pp. 427-428.

55 'Uniwersał podwodny warszawski', 28 III 1564 Warszawa, Volumina Constitutionum, t. II, Vol. 1, p. 144: 'Gdyżeśmy w teiże mierze przedtem w Księstwie Naszym Litewskim postanowienie uczynili, a tak też $i w$ Koronie, na teraźniejszym sejmie koronnym warszawskim, za rada $i$ za spolnym zezwoleniem rad Naszych $i$ innych stanow na tym to sejmie zgromadzonych, postanowiliśmy.' Universal's overview: S. Kutrzeba, 'Podwody..., pp. 506-5o9; A. Pawiński, Skarbowość..., pp. 112-117; H. Karbownik, Ciężary stanu duchownego w Polsce na rzecz państwa od roku 1381 do potowy XVII wieku (Lublin, 1980), pp. 89-91.

${ }^{56}$ S. Wysłouch, Powinności..., p. 5 . 


\section{of its Lithuanian counterpart. ${ }^{57}$ The table below summarises the similarities and differences in both legal systems.}

\begin{tabular}{|c|c|c|}
\hline $\begin{array}{l}\text { Similarities (S) / } \\
\text { Differences (D) }\end{array}$ & Grand Duchy of Lithuania & Crown \\
\hline Purpose of the tax (S/D) & $\begin{array}{l}\text { Providing funds for transport } \\
\text { service provision, creating tran- } \\
\text { sport service treasury }\end{array}$ & $\begin{array}{l}\text { Providing funds for trans- } \\
\text { port service provision spent } \\
\text { by the Treasury writer }\end{array}$ \\
\hline Form of the document (S) & $\begin{array}{l}\text { The grand duke's proclama- } \\
\text { tion issued with the coun- } \\
\text { cillors }\end{array}$ & $\begin{array}{l}\text { The king's proclamation is- } \\
\text { sued in the Sejm with the } \\
\text { participation of the Council }\end{array}$ \\
\hline Taxed entities (D) & $\begin{array}{l}\text { All towns, as well as landed } \\
\text { property obliged to provide } \\
\text { transport services (the service) }\end{array}$ & $\begin{array}{l}\text { Royal towns and certain } \\
\text { clergy towns (occasionally } \\
\text { villages) }\end{array}$ \\
\hline $\begin{array}{l}\text { Indirectly burdened cate- } \\
\text { gories (D) }\end{array}$ & $\begin{array}{l}\text { On the road network, settle- } \\
\text { ments not paying taxes but } \\
\text { obliged to provide horses for } \\
\text { remuneration }\end{array}$ & None \\
\hline Tax base $(\mathrm{D})$ & $\begin{array}{l}\text { Real taxation on the number } \\
\text { of houses (smokes) and land } \\
\text { owned; receivables changed } \\
\text { over time }\end{array}$ & $\begin{array}{l}3 / 4 \text { of the szos property tax } \\
\text { (a flat-rate method, based } \\
\text { on old receipts), the size of } \\
\text { which in principle remains } \\
\text { unchanged; occasionally ac- } \\
\text { tually taxed villages }\end{array}$ \\
\hline $\begin{array}{l}\text { Number of instalments } \\
\text { paid per year (D) }\end{array}$ & 2 & 1 \\
\hline $\begin{array}{l}\text { Method of tax payment } \\
\text { (D) }\end{array}$ & None & $\begin{array}{l}\text { Collecting records from sta- } \\
\text { rosts, receipts, remunera- } \\
\text { tion for town writers } 3 \text { or } 5 \\
\text { groszy villages/towns }\end{array}$ \\
\hline Treasury type (D) & Land Treasury & Court Treasury \\
\hline $\begin{array}{l}\text { Relationship to suburbs } \\
\text { (S/D) }\end{array}$ & $\begin{array}{l}\text { Taxation of suburban resi- } \\
\text { dents, which increases the glo- } \\
\text { bal tax volume }\end{array}$ & $\begin{array}{l}\text { Taxation of suburban resi- } \\
\text { dents, which does not in- } \\
\text { crease the global tax volume }\end{array}$ \\
\hline Tax collector $(\mathrm{S} / \mathrm{D})$ & $\begin{array}{l}\text { Leaseholder-governor (sta- } \\
\text { rost) or land official (ensign) }\end{array}$ & Starost \\
\hline Tax exemptions (S) & $\begin{array}{l}\text { Commune mayor/mayor su- } \\
\text { pervising the collection of } \\
\text { tax in the settlement }\end{array}$ & $\begin{array}{l}\text { Commune mayor/mayor su- } \\
\text { pervising the collection of } \\
\text { tax in the settlement }\end{array}$ \\
\hline
\end{tabular}

Table 1. A comparison of the transport service tax in the Crown and the Grand Duchy of Lithuania during the reign of Zygmunt August. Study based on: Russkaia istoricheskaia biblioteka, t. XXX: Litovskaia metrika, Otd. 1-2, chap. 3 (Knigi publichnykh del, t. 1), ed. I.I. Lappo (Yur'iev, 1914), pp. 161-162, 218-219, 592-599; Volumina Constitutionum, t. II: 1550-1609, Vol. 1: 1550-1585, ed. S. Grodziski, I. Dwornicka, W. Uruszczak (Warszawa, 2005), ed. 144-146.

${ }^{57}$ J. Jaroszewicz, Obraz Litwy pod względem jej cywilizacji od czasów najdawniejszych do końca wieku XVIII, Vol. 2 (Wilno, 1844), p. 120. 
There is no doubt that, in essence, the Polish solution was very strongly inspired by Lithuanian solutions. However, the solutions were very different in terms of details. In my opinion, the most important difference was the different taxation philosophy. In Lithuania, this was real taxation that could be verified in the future. In the Polish Crown, on the other hand, szos property tax was adopted, which by the second half of the $15^{\text {th }}$ century was a lump sum tax, and was selected based on old receipts. ${ }^{8}$ Thus, the taxation on the Crown suburbs did not increase tax revenues, but just reduced the payers' liabilities. As a result, in the grand duchy, tax rates were subject to significant changes, while they remained unaltered in the Crown throughout the second half of the 16th and the first half of the $17^{\text {th }}$ century.59 An example is Orsha, which in the 155 os and 156 os paid five kopas groszy (12.5 zlotys), while in the period 1642 to 1644 , the town contributed 52 zlotys and six groszy annually to the Treasury. ${ }^{60}$

Different standards functioning in the Crown resulted in some residents in Poland not paying tax. For example, the Jews were obliged to pay the per capita tax (pogtówne), ${ }^{61}$ but there were no special regulations for the townspeople who owned landed property. This was fully visible in the towns annexed by the Crown of the Kingdom of Poland as a result of the 1569 incorporation. The townspeople obviously saw the injustice of this solution and demanded changes. Hence, in Lutsk, Sigismund III Vasa estimated that Jews constituted almost half the town's population, so he ordered

${ }^{58} \mathrm{~K}$. Boroda, 'Przeszłość przeliczników demograficznych dla szesnastowiecznych źródeł podatkowych', Przeszłość Demograficzna Polski, Vol. 37, No 2 (2015), pp. 27-52.

${ }^{59}$ In 1635 , Kalisz still paid 96 zlotys according to old settlements, by analogy with Piwniczna, which in 1629 was still obliged to pay one zloty and six groszy, or Mława, where nine zlotys and 22 groszy in transport service tax was still paid. Archiwum Państwowe w Poznaniu, Akta miasta Kalisza, ref. 186, p. 28; H. Stamirski, Zarys rozwoju miasta Piwnicznej (lata 1348-1807) (Nowy Sącz, 1961), p. 63; Lustracje województwa ptockiego: 1565-1789, ed. A. Sucheni-Grabowska, S. M. Szacherska (Warszawa, 1965), pp. 79, 100.

6o 'Liczba pieniędzy stołowych królewskich, przyjętych i wydanych' (14 III 1644), AGAD AR, II, ref. 1211, p. 5; Lietuvos Metrika (1567-1569), knyga nr. 531, ed. L. Anužytė, A. Baliulis (Vilnius, 2001), p. 128 (doc. 126).

${ }^{61}$ A. Filipczak-Kocur, Skarbowość..., pp. 65-66, 257-258. 
them to pay a third of the transport service tax, and provide pro rata transport services to enforcement officers. Part of the burden also fell on the Jewish community in Volodymyr-Volynskyi. ${ }^{62}$ In Podlasie, the starosts tried to appropriate the transport service tax relating to the town's wtókas as the starosty's income. Thus, commissioners inspecting the starosty of Knyszyn in 1616 noted that out of 130 wtókas of land which the townspeople owned, they had to pay 16 zlotys and 22.5 groszy (which makes on average 3.9 groszy per wtóka). The money had been collected by the starosts so far. In addition, the transport service tax was supposed to include fees paid by craftsmen (149 people), innkeepers, etc, which amounted to 21 zlotys and 15 groszy ${ }^{63}$ This inspection shows that the taxation of the towns annexed by the Crown was based on pre-union Lithuanian law. This hypothesis needs to be verified.

On the other hand, the situation in the Crown was much better regarding the tax payment procedure. Firstly, it was decided that one instalment a year should be paid, which, given the small amounts and high costs of meeting the tax obligation, was a reasonable solution. Secondly, clear criteria were introduced for the collection of certificates from the starost, and the census amounts paid to the writer were established. This issue was partly regulated by the 1568 Lithuanian tax ordinance. Treasury writers were to receive remuneration based on issued receipts from revenue. In principle, the issue of receipts cost 14 or 12 groszy, except for transport service tax, whose receipt for payment cost only six groszy ${ }^{64}$

Greater control of starosts introduced in the Crown was also advisable, as the Lithuanian experience in this area was disastrous. My conclusion is based on two situations. The first one concerns the settlement by his sons of the claims after the death of Mikołaj

${ }_{62}^{62}$ Declaratia z strony dawania podwod miastu Łuckowi dana', Warszawa 22 II 629, in: Riksarkivet (Stockholm), Skoklostersamlingen, E 8636, p. 45v; M. Bałaban, Studja historyczne (Warszawa, 1927), p. 41; A. Pawiński, Skarbowość..., p. 116.

${ }^{63}$ 'Lustracja miasta Knyszyna w starostwie knyszyńskim' (Knyszyn) 1616, in: Prawa i przywileje miasta Knyszyna 1506-1795. Monografia historyczna miasta Knyszyna z uwzględnieniem najnowszych badań archiwalnych, ed. J. Maroszek (Knyszyn, 2018), pp. 114, 116. Cf. Lustracja województwa podlaskiego 1602 roku, ed. M. Sierba (Warszawa, 2017), pp. 5-6, 64 .

${ }^{64}$ AGAD AR, II, ref. 59, pp. $1-3$. 
Radziwiłł 'The Black'. It was not until 1568 that they settled the funds for transport service provision, collected from Brest-Litovsk in the period 1558 to 1565 . The town paid 1oo kopas a year, so 8 oo kopas were handed over to the Treasury straightaway. ${ }^{65}$ Likewise, in the same year, transport service tax arrears from the town of Orsha for the period 1557 to 1567 were demanded. After a close examination of the circumstances, it turns out that until 1566 the townspeople paid the transport service tax to the leaseholder (starost) Andrej Odincewicz, who kept it for himself. ${ }^{66}$

By analogy with the Second Lithuanian Statute, the Third Lithuanian Statute also did not record the existence of transport service tax. The pattern established in 1529 indicated freedom from commercial transport service provision, and the obligation to provide transport services for the benefit of messengers, envoys and the grand duke. ${ }^{67}$ The first common transport service provision proclamation referring to the Polish-Lithuanian Commonwealth,

${ }^{65}$ Lietuvos Metrika (1566-1574)..., p. 195 (doc. 139). Brest-Litovsk paid 250 zlotys a year, which is more than the transport service tax paid by the Polish Crown towns (which were to pay three quarters of the szos), with the exception of Krakow (1500), Poznań (525) and Lviv (300). A. Pawiński, Skarbowość..., pp. 114-116, 156 (it is wrongly mentioned that Lviv was to pay 600 zlotys; in fact, it was 72 zlotys). However, all three aforementioned Crown towns were exempted from this tax. The larger transport service taxpayers also included Grodno, which paid 5o kopas groszy annually. Akty Vilenskoy arkheograficheskoy komissii, t. VII: Akty Grodnenskogo gorodskogo suda (Vil'no, 1874), doc. 17, pp. 86-87.

${ }^{66}$ Lietuvos Metrika (1567-1569)..., p. 128 (doc. 126).

${ }^{67}$ Statut Wielkiego Księstwa Litewskiego, Wilno 1819, chap. III, art. 29, pp. 73-74. In subsequenteditionsoftheStatute, therespectivearticleslisted therelatedconstitutions. Laws passed by the Sejm in 1601, 1658 and 1673 were connected with transport service provision. In addition, the following documents were mentioned:royal proclamations, Stefan Batory's in 1576, and, as is characteristic of Zygmunt August, the proclamation announced for the Crown lands in $\mathbf{1 5 6 4}$. See 'Uniwersał podwodny warszawski', 28 III 1564 Warszawa, Volumina Constitutionum, t. II, Vol. 1, pp. 144-146 (Uniwersat o podwodach z sejmu toruńskiego z dn. 29 XI 1576), (Toruń, 1576)(https://polona.pl/ item/uniwersal-o-podwodach-z-sejmu-torunskiego-z-dn-29-xi-1576-inc-stephanz-laski,NzUyNjQ4NTM/o/\#info:metadata; accessed 10 December 2019); 'Ordynatia około dawania i płacenia podwod', Kraków 29 XI 1576, in: A. Karabowicz, 'Sprawy sejmowe i dorobek prawodawczy "tempore Conventi Generalia Toruniensis A.D. 1576 " w świetle Metryki Koronnej', Krakowskie Studia z Historii Państwa i Prawa Vol. 2 (2008), pp. 86-87; 'O podwodach', Volumina Constitutionum, t. II, Vol. 2, p. 397; 'Ordynacya poczty W.X.Lit.', Volumina Legum, t. V, ed. J. Ohryzko (Petersburg, 186o), p. 9 . 
the Republic of the Two Nations, was issued by Stefan Batory in 1576, and then repeated almost unchanged two years later. ${ }^{68}$ As regards the tax itself and the transport service treasury, it did not substantially change the existing rules. A provision was added to stipulate a four-year tax exemption privilege (wolnizna) in the event of damage by the enemy or fire. The key changes concerned the rules for paying and enforcing the transport service tax. From then on, the tax had to be paid once a year at Pentecost, i.e. at the end of the first half of the year (May-June). Thus, the two tax instalments were eliminated, and the tax had to be paid directly to the Treasury, or to specially appointed collectors. The existing regulations were found to be ineffective. The delay was to result in a penalty equal to the amount of tax arrears. A decision was made to resign from the royal court (as a rule, the royal court [asesoria]) as the competent body to handle fiscal matters, and court starosts were authorised to carry out enforcement as demanded by the beneficiary of the transport service (if transport service was not provided to them) or representatives of the Royal Treasury. Half the amount was to be granted to the starost, which was to lead to the effective recovery of tax claims. The presumption of an obligation to pay an amount equivalent to transport service provision and to pay transport service tax was therefore introduced. Two years later (1578), the king added a provision prohibiting reference to any freedoms whatsoever to avoid tax obligations. Treasury receipts and decisions brought by the tax messenger were to be the only documents with legal force.

The transformation of the transport service tax and Treasury took place at the end of the reign of Władysław IV. Already in 1620, the Constitution announced far-reaching changes and the replacement of transport service provision by postal services. ${ }^{69}$ However, it was not until the 1647 Constitution was adopted

${ }^{68}$ 'Uniwersał na podwody', Warszawa 4 III 1578, Volumina Constitutionum, t. II, Vol. 1, pp. 420-421; 'Ordynatia około dawania i płacenia podwod', Toruń 29 XI 1576, A. Karabowicz, 'Sprawy..., pp. 86-87.

${ }^{69}$ Volumina Constitutionum, t. II, Vol. 2, p. 286, pkt 77; Volumina Constitutionum, t. III: 1611-1640, Vol.1:1611-1626, ed. S. Grodziski, M. Kwiecień, A. Karabowicz, Warszawa 2010, p. 274, pt 31; Cf. I. Lewandowska-Malec, Sejm walny koronny Rzeczypospolitej Obojfa Narodów i jego dorobek ustawodawczy (1587-1632) (Kraków, 2009), p. 391. 
that the transport service provision duty was abolished (except for foreign missions). This was to be replaced by postal services, maintained by the Treasury created from the previous transport service tax. The tax was raised fourfold, and was supposed to be handed over on 11 November (St Martin's Day) to the post office representative Karol Montelupi, or an official designated by him. It was emphasised that the amount of tax would be confirmed by the office with the king's signature. Tax arrears were to be punished to the sum of double the tax debt, and the royal court was to have subject matter jurisdiction..$^{70}$

At the end of the deliberations, the amount of revenue generated by transport service tax in the Grand Duchy of Lithuania should be considered. Unfortunately, in view of the destruction of tax records and the variable tax base, I can only provide estimates. I can recreate the amount, or rather the collectability, of the transport service tax in the Grand Duchy of Lithuania on the basis of the accounts of the treasurer Ostafi Wołłowicz between 1561 and $1566 .^{71}$ He estimated revenue from the transport service tax for four years, eight months and 14 days at 4,575 kopas and 12 groszy It was noted that the tax was collected not only from state property, but also from private estates. Obviously, there were also tax arrears, but I believe they were of a different nature than in the Crown. In Lithuania, the payers were more willing to pay for transport service provision, for otherwise they had to fulfil free transport service provision duties, which discouraged them from

${ }^{70}$ Ordynacya poczty', Volumina Constitutionum, t. IV: 1641-1668, Vol. 1: 1641-1658, ed. S. Grodziski, M. Kwiecień, K. Fokt (Warszawa, 2015), p. 95. The abolition of transport service provision and a tax increase were introduced a year earlier by Władysław IV, by way of a proclamation. Zniesienie podwód miast i miasteczek tak królewskich jak i duchownych we wszystkiej Koronie Polskiej dawanych, Warszawa 25 IV 1646, Archiwum Gtówne Akt Dawnych, Metryka Koronna (henceforth AGAD MK) 189, k. 421v-423; (Uniwersał podwodowy), Warszawa 25 IV 1645 (!), P. Dąbkowski, Zbiór dokumentów do historji urządzeń pocztowych w Polsce (Lwów, 1928), pp. 24-25. I am not aware of any equivalent of the proclamation in the Grand Duchy of Lithuania.

${ }^{71}$ 'Kvitantsiya Podkan'tslerogo marshalka dvornogo Volovicha zo vsego chasu podskarbstva yego mlti i sovseye sumy na prikhode i raskhode polozhonoye i okazanoye vechnym' chasom", RGADA, f. 389, No 48, f. 224-229v. 
falling behind with payments. ${ }^{72}$ It was the starosts and leaseholders who kept the money, as is evidenced by the examples of Brest-Litovsk and Orsha. ${ }^{73}$ There were far more arrears, but it is not clear whether they had been eliminated by 1566 . For example, in 1562 , a letter was sent to 11 towns, demanding outstanding transport service taxes. ${ }^{74}$ After the conversion of Lithuanian currency into Polish zlotys, the revenue amounted to 11,438 zlotys. This meant that about 2,408 zlotys was deposited in the Land Treasury annually. Orsha and Brest Litovsk should be added to this, which increases the annual revenue to 2,670.50 zlotys.

These estimates should be viewed with caution, as they tend to represent minimum budgetary receipts. Other results provide the settlements of the Lithuanian Treasury during Stefan Batory's reign. ${ }^{75}$ In 1580, 2,629 kopas were obtained from rents and transport service provision funds, and a year later an additional 839 kopas came from rents. It can be concluded with great caution that the transport service tax brought in 1,789 kopas and 17 groszy (about 4,473 zlotys). This is much more than in the days of Zygmunt August, but the value seems likely. It should be noted that in the Polish Crown, Stefan Batory structured and maximised income from transport service provision thanks to two proclamations, in 1576 and 1578. Presumably, the same happened in Lithuania. However, it is likely that the amount was significantly increased by tax arrears. As a rule, during Stefan Batory's reign, the towns paid their debts for two or three years. It is safest to assume that the revenue from the transport service tax was in the range of 2,700 to 4,400 zlotys. ${ }^{76}$

${ }^{72}$ Akty, otnosiashchiesia k istorii Zapadnoi Rossii, t. III, doc. 24, pp. 100-101; Zygmunt August to B.F. Korecki, Grodno 12 I 1567, in: Arkhiv Yugo-zapadnoy Rossii, chap. 8, t. 5, pp. 156-157.

${ }^{73}$ Apart from the aforementioned examples of Brest Litovsk and Orsha, the same applied to Krzemieniec. Lietuvos Metrika. Knyga Nr. 52, 1569-1570. Užrašymų knyga 52, ed. A. Baliulis, R. Firkovičius (Vilnius, 2004), p. 139.

${ }^{74}$ Lietuvos Metrika kn. 564 (1553-1567)..., doc. 106, p. 109.

${ }^{75}$ 'Rozliczenie podskarbich litewskich' Wilno 20 I 1582, in: Opisaniye rukopisnago otdeleniia Vilenskoi Publichnoi Biblioteki, Vyp. 3 (Vil'no, 1898), pp. 88-91.

${ }^{76} \mathrm{My}$ calculations indicate that the transport service tax in the Crown after its introduction in 1564 could have potentially brought in 6,626 zlotys, but after obtaining exemptions in the first years of its existence it decreased by 2,361 zlotys (to 4,265 zlotys). 
The above estimate is also likely to be supported by the content of the Constitution of 1673. It introduced a lump-sum transport service tax from the Grand Duchy of Lithuania, which amounted to 12,00o zlotys. It was to be paid into the Lithuanian Post Treasury (to Reinhold Bizing). Obviously, it was four times the transport service provision, so on average an ordinary transport service provision should yield 3,00o zlotys. At the same time, it should be noted that the times of economic collapse, the ravages of wars with the Tsar of Muscovy, the Swedes and the looting by military confederations are referred to. It would be extremely valuable to gain an insight into the key for dividing this amount into the towns, as stated in the Constitution. Unfortunately, I am not aware of the existence of such a document. ${ }^{77}$

Was this revenue sufficient to maintain state transport? According to Ostafi Wołłowicz's settlements, the expenses in relation to transport service provision revenue were irregular. The Land Treasury annually spent about 10,00o zlotys (9,984 zlotys) on transport service provision, four times more than the declared revenue. ${ }^{7}$ It should be stressed, however, that the real revenue was probably much higher, while the expenses provided probably included the costs of state missions. We have more detailed information at our disposal for 1580 : this is when the Lithuanian Treasury spent 2,843 zlotys on messengers. Significantly larger sums were spent on missions $(6,327$ zlotys was spent on Vallachia and Moscow missions); and three Tartar missions together with gifts cost the State Treasury 17,230 zlotys. The enforcement officers guarding and transporting prisoners of war should be added to this, which resulted in spending another 2,194 zlotys. It can therefore be concluded that the transport service tax more than met

77 'Ordynacya poczty W.X.Lit.', Volumina Legum, t. V, p. 9o. E. Długopolski, 'Dąbkowski Przemysław Dr.: Rys urządzeń pocztowych w dawnej Polsce. Kraków, nakładem autora, 1903, str. 93', in: Kwartalnik Historyczny, Vol. 18 (1904), p. 549. E. Dlugopolski mistakenly states that the lump sum revenue was to amount to 1,200 zlotys from 1673 .

${ }^{78}$ 'Kvitantsiya Podkan'tslerogo marshalka dvornogo Volovicha zo vsego chasu podskarbstva iego mlti i sovseie sumy na prikhode i raskhode polozhonoie i okazanoie vechnym' chasom", RGADA, f. 389, No 48, f. 224-229v. 
the needs of state transport in a strict sense, even though higher in times of war. However, the tax could not cover the cost of state missions. The situation was different in the 17 th century. In 1601 , the Constitution doubled the cost of horse rental, which meant that expenses would have almost doubled. ${ }^{79}$ These assumptions are reflected in the structure of Lithuanian Treasury expenses for two years: 1633 and 1634. At that time, 9,625 zlotys was spent on messengers, and $3,75^{6}$ zlotys on the post, which means annual expenses in the order of 6,69o zlotys. On the other hand, in 1636 and for half a year in 1637, transport service provision costs of 7,242 zlotys (about 4,828 zlotys per year) were incurred. ${ }^{80}$ This means that the transport service tax as a dedicated charge to ensure transport within the state, even without a military and diplomatic element, was no longer sufficient.

Transport service provision as part of the budget of the Land Treasury in the $17^{\text {th }}$ century disappears from the accounts of treasurers before the Sejm, possibly bringing in negligible amounts (several dozen or a few hundred zlotys). ${ }^{81}$ As I see it, the reason for that was similar to that in the Crown. The transport service tax as permanent and annual revenue was ideal as collateral for a loan or as a way of awarding prizes and offering remuneration. ${ }^{82}$ This phenomenon is visible on a small scale during the reign of Stefan Batory, while a huge drop in actual tax revenue occurred during the reign of Sigismund III. ${ }^{8_{3}}$ Already at the beginning of Vasa's reign, the receivables based on the transport service tax reduced the

79 'O podwodach', Volumina Constitutionum, t. II, Vol. 2, p. 397.

${ }^{80}$ A. Filipczak-Kocur, Skarbowość..., pp. 318, 323.

${ }^{81}$ 'Liczba pieniędzy stołowych królewskich, przyjętych i wydanych' (14 III 1644), in: AGAD AR, II, ref. 1211, p. 5; A. Filipczak-Kocur, Skarbowość..., pp. 264-329.

${ }^{82}$ For example, on 25 March 16o9, Sigismund III offered the Crown treasury custodian Fr Waligórski four zlotys per week and an additional ten zlotys per year (218 zlotys in total). The money was to be collected personally from transport service fees from Kazimierz near Krakow (70 zlotys), Wieliczka ( 54 zlotys), Bochnia (42 zlotys), Oświęcim ( 36 zlotys) and Skawina ( 16 zlotys). This remuneration had a much longer tradition, because his predecessor in this position, Szymon Turski, received a wage of three zlotys a week, in the same mode (without Oświęcim and Skawina). Biblioteka Książąt Czartoryskich, ref. 104, doc. 147, pp. 643-645.

${ }^{8}$ This was due to the huge debts that Sigismund III had incurred at the beginning of his reign. A. Filipczak-Kocur, Skarbowość..., pp. 371-375. 
real revenue in the Crown from 4,00o to 3,00o zlotys, and plans for 1590 provided for 'transport service money impoverished; little will be placed in the Treasury'. ${ }^{84}$ Interestingly enough, two years later, the whole revenue from transport service provision was given by the king as remuneration to the crown treasurer Jan Firlej. ${ }^{85}$ Similar occurrences led to the treatment of the revenue from the transport service tax as one of many elements of revenue, so the aim of the tax was $\operatorname{lost}^{86}$.

The transport service tax was the only permanent tax from the 155 os until the reign of Władysław IV. It generated annual revenue in the range of 2,700 to 4,400 zlotys, and ensured the basic functioning of state transport carried out through transport service provision. The Treasury guardian, along with the Treasury writer, was responsible for the receipt of the transport service tax and the expenses associated with transport service provision. This revenue was part of the Land Treasury, hence it was different from the relations existing in Poland. There were many more differences than similarities between the Grand Duchy of Lithuania and the Crown, as is shown in Table 1. The most important difference was the tax base, which in Lithuania had a real base, as opposed to the $3 / 4$ of the lump-sum szos in the Crown.

The proclamations by Stefan Batory of 1576 and 1578 unified the rules on the collection and enforcement of tax arrears, and introduced an obligation to pay the tax once, rather than twice a year, as was customary before. From then on, the money was to be delivered directly to the Treasury, or to designated tax collectors. On the other hand, the arrears were not to be settled by the grand duke's court (until 1569) or the Sejm court, but directly by the starosts, who collected a penalty fee equal to the tax arrears

${ }^{84}$ Tsentral'niy derzhavniy istorichniy arkhiv Ukraïni, m. Kiïv, f. 1, op. 1, spr. 2, f. 174.

${ }^{85}$ AGAD MK, ref. 137 , f. $57 \mathrm{~V}^{-}-58$.

${ }^{86}$ Sigismund III transferred the municipal fees from Mogilev (including the transport service tax) to the heirs of the Vitebsk castellan Marcin Strawiński, who died in 1594. 6, ooo zlotys of the debt was to be repaid within 20 years. Lietuvos valstybès istorijos archyvas (henceforth - LVIA), F. 289, b. 83, f. 77; F. 289, b. 84, f. 43v-44. 
collected. This reform was connected with negative experiences from previous years, in which collectors (leaseholders, governors, starosts) collected payments from towns for many years, but never transferred them to the Treasury.

Transport service provision reform was implemented between 1546 and 1559. Of key importance was the Constitution of 1551, which introduced an annual transport service tax on landed property (including private property), in the past burdened with transport service provision. The rules concerning towns and the announcement of the establishment of a special treasury to guarantee the payment of money to travelling messengers, officials and envoys were issued in the form of the grand duke's proclamation in 1558 . The fierce resistance by the nobility should be emphasised, which was reflected in numerous debates on the issue in the Lithuanian Sejm (the last time in 1567). In my opinion, this experience led Sigismund II Augustus to withdraw from reforms based on permanent taxes, in favour of extraordinary taxes. They were much more easily granted by the nobility, and yielded far greater revenue.

This is confirmed by a list of all land revenues, including very high extraordinary taxes announced for military activities during the war with Muscovy (1558-1570). Transport service revenue from the 156 os accounted for a modest $0.48 \%$ of the total amount. As the revenue from the transport service tax stabilised, it could be expected to play an important role. This is confirmed in the accounts of 1581. The expenses of the Land Treasury amounted to 63,321 zlotys; thus the transport service provision constituted $7 \%$, and together with the court treasury $2.96 \%$ (the total revenue amounted to 150,925 zlotys) ${ }^{87}$ On the other hand, without the adoption of extraordinary taxes, these were the only revenues of the Land Treasury until 1632, when in the pacta conventa, Władysław IV undertook to allocate the quarterly tax as part of the public Treasury. The quarterly tax was to be paid only after the

${ }^{87}$ 'Rozliczenie podskarbich litewskich', Wilno 20 I 1582, in: Opisaniie rukopisnago otdeleniia..., pp. 88-91; 'Kvitantsiia Podkan'tslerogo marshalka dvornogo Volovicha zo vsego chasu podskarbstva ego mlti i sovseie sumy na prikhode i raskhode polozhonoe i okazanoe vechnym' chasom", RGADA, f. 389, No 48, f. 224-229v. 
death of the current leaseholders, so the actual revenue appeared only in the 1640 . The revenue from the quarterly tax for the first eight years of its functioning as a permanent tax (1633-1640) amounted to 3,700 zlotys per year, hence it was comparable to the revenue from transport service provision. ${ }^{88}$

In the $17^{\text {th }}$ century, transport service tax revenue was no longer sufficient due to increased expenses. Above all, however, the tax ceased to generate real income to the State Treasury, as it became a way to secure loans, a form of an award and permanent remuneration. The Constitution of 1647 was an attempt to 'fix' the transport service tax. It was quadrupled and ordered to be transferred to the post which was being established at that time. From 1673, in the Grand Duchy of Lithuania, it was to be a lump sum tax amounting to 12,000 zlotys.

Author Details

Karol Łopatecki is a professor at the Faculty of History and International Relations at the University of Białystok. His fields of interest include history of law and history of military organisation, with a particular emphasis on the theory of state capacity and the military revolution. He also conducts research on cartography, as well as regional history of Podlasie and the Branicki family. $\mathrm{He}$ is a member of the Commission for Lithuanian Studies and the Military History Group of the Committee of Historical Sciences at the Polish Academy of Sciences.

Email: karollopatecki@gmail.com; k.lopatecki@uwb.edu.pl.

\section{Bibliography}

AUGUSTYNIAK, Urszula. W stużbie hetmana i Rzeczypospolitej. Klientela wojskowa Krzysztofa Radziwitta (1585-1640) (Warszawa, 2004).

BAŁABAN, Majer. Studja historyczne (Warszawa, 1927).

BORODA, Krzysztof. 'Przeszłość przeliczników demograficznych dla szesnastowiecznych źródeł podatkowych', in: Przeszłość Demograficzna Polski, Vol. 37, No 2 (2015), pp. 27-52.

\footnotetext{
${ }^{88}$ A. Filipczak-Kocur, Skarbowość..., pp. 246-249, 259-262.
} 
DŁUGOPOLSKI, Edmund. 'Dąbkowski Przemysław Dr.: Rys urządzeń pocztowych w dawnej Polsce. Kraków, nakładem autora, 1903, str. 93', in: Kwartalnik Historyczny, Vol. 18 (1904), pp. 543-552.

FELIS, Paweł. Elementy teorii i praktyki podatków majątkowych. Poszukiwanie ładu w opodatkowaniu nieruchomości w Polsce z perspektywy przedsiębiorców orazjednostek samorzadu terytorialnego (Warszawa, 2012).

FILIPCZAK-KOCUR, Anna. Skarbowość Rzeczypospolitej 1587-1648 (Warszawa, 2006).

GĄSIOROWSKI, Antoni. 'Itinerarium dwu ostatnich Jagiellonów', in: Studia Historyczne, Vol. 16, No 2 (1973), pp. 249-275.

JAROSZEWICZ, Józef. Obraz Litwy pod względem jej cywilizacji od czasów najdawniejszych do końca wieku XVIII, Vol. 2 (Wilno, 1844).

JURKIEWICZ, Jan. 'Podróże chłopów Wielkiego Księstwa Litewskiego w XVI-XVIII w. (z zagadnień powinności transportowych włościan)', in: „Mtodsza Europa” od średniowiecza do wspótczesności. Prace ofiarowane Profesor Marii Barbarze Piechowiak Topolskiej w siedemdziesiąta rocznice urodzin, ed. J. Jurkiewicz, R.M. Józefiak, W. Strzyżewski (Zielona Góra, 2008), pp. 301-320.

JURKIEWICZ, Jan. 'Powinności podwodowe włościan w Wielkim Księstwie Litewskim (XVI-XVIII w.). Z zagadnień ich terminologii i klasyfikacji', in: Istorijos akiračiai. Skiriama profesoriaus habilituoto daktaro Antano Tylos 75-mečiui, ed. E. Rimša (Vilnius, 2004), pp. 101-126.

KAMIENIECKI, Witold. 'Chorążowie w parlamentaryzmie litewskim przed unią lubelską', in: Antemurale, Vol. 9 (1965), pp. 165-202.

KANECKI, Oskar. 'Recepcja urzędu dzieckiego z Rusi do struktur państwowych Wielkiego Księstwa Litewskiego', in: Pogranicza w historii prawa i myśli polityczno-prawnej, ed. D. Szpoper, P. Dąbrowski (Gdańsk-Olsztyn 2017), pp. 269-276.

KARABOWICZ, Anna. 'Sprawy sejmowe i dorobek prawodawczy „tempore Conventi Generalia Toruniensis A.D. 1576” w świetle Metryki Koronnej', in: Krakowskie Studia z Historii Państwa i Prawa, Vol. 2 (2008), pp. 73-9o.

KARBOWNIK, Henryk. Ciężary stanu duchownego w Polsce na rzecz państwa od roku 1381 do potowy XVII wieku (Lublin, 1980).

KRZYŻANOWSKI, Stanisław. 'Podwody kazimierskie 1407-1432', in: Archiwum Komisyi Historii, t. XI (Kraków, 1912), pp. 392-465.

KUTRZEBA, Stanisław. 'Podwody miast polskich do roku 1564', in: Przewodnik Naukowy i Literacki, Vol. 27, No 5 (1900), pp. 495-509.

LESMAITIS, Gediminas. Wojsko zaciężne w Wielkim Księstwie Litewskim w końcu XV-drugiej potowie XVI wieku, trans. B. Piasecka (Warszawa, 2013). 
LEWANDOWSKA-MALEC, Izabela. Sejm walny koronny Rzeczypospolitej Obojga Narodów i jego dorobek ustawodawczy (1587-1632) (Kraków, 2009).

ŁOPATECKI, Karol. Organizacja, prawo $i$ dyscyplina $w$ polskim $i$ litewskim pospolitym ruszeniu (do połowy XVII wieku) (Białystok, 2018).

ŁOWMIAŃSKI, Henryk. 'Posługi komunikacyjne w miastach W. Ks. Litewskiego na prawie magdeburskiem do połowy XVI w., S. Wysłouch, Wilno 1936', in: Ateneum Wileńskie, Vol. 12 (1937), pp. 599-6o3.

ŁOWMIAŃSKI, Henryk. Studia nad dziejami Wielkiego Księstwa Litewskiego (Poznań, 1983).

LYUBAVSKII, Matvei. Litovsko-russkii Seim. Opyt po istorii uchrezhdeniia $v$ sviazi s vnutrennim stroem i vneshnei zhizn'iu gosudarstva (Moskva, 19oo).

LYUBAVSKII, Matvei. Ocherk istorii Litovsko-Russkogo gosudarstva do Liublinskoi unii vkliuchitel'no (Moskva, 1910).

PAWIŃSKI, Adolf. Skarbowość w Polsce i jej dzieje za Stefana Batorego (Warszawa, 1881).

PETERSEN, Ladewig E. 'From domain state to tax state', in: Scandinavian Economic History Review, Vol. 23, No 2 (1975), pp. 116-148.

POLECHOW, Sergiej. 'Itinerarium wielkiego księcia litewskiego Witolda: 4/5 sierpnia 1392 - 27 października 143o', in: Rocznik Lituanistyczny, Vol. 5 (2019), pp. 9-120.

PUŁASKI, Kazimierz. 'Powinności wojskowe mieszczan w danych miastach na Rusi', in: Biblioteka Warszawska, Vol. 4 (1872), pp. 254-265.

RACHUBA, Andrzej. Wielkie Księstwo Litewskie w systemie parlamentarnym Rzeczypospolitej w latach 1569-1763 (Warszawa, 2002).

SROGOSZ, Tadeusz. 'Ekonomiczne i społeczne następstwa przemarszów oraz stacjonowania wojsk własnych na terenie województw łęczyckiego i sieradzkiego oraz ziemi wieluńskiej w XVII wieku', in: Acta Universitatis Lodziensis. Folia Historica, Vol. 37 (199o), pp. 3-33.

STAMIRSKI, Henryk. Zarys rozwoju miasta Piwnicznej (lata 1348-1807) (Nowy Sącz, 1961).

SZULC, Dominik. 'Litewskie reformy ustrojowe lat $1564-1566$ a sprawa unii polsko-litewskiej. Podsumowanie problemu w 45o-tą rocznicę wejścia w życie II Statutu Litewskiego', in: Skhidnoevropeyskiy istorichniy vicnik/ East European Historical Bulletin, Vol. 3 (2017), pp. 12-21.

TYLA, Antanas. 'Lietuvos rūmų iždas: pajamų šaltiniai ir jų panaudojimas (XVI a. pab. - XVII a.)', in: Lietuvos istorijos metraštis, 1995 (1996), pp. $29-48$.

TYLA, Antanas. Lietuva ir Livonija XVI a. pabaigoje - XVII a. pradžioje (Vilnius, 1986). 
WISNER, Henryk. Rzeczypospolita Wazów, t. I: Czasy Zygmunta III $i$ Wtadystawa IV (Warszawa, 2002).

WISNER, Henryk. Rzeczpospolita Wazów, t. II: Wojsko Wielkiego Księstwa Litewskiego, dyplomacja, varia (Warszawa, 2004).

WISNER, Henryk. Rzeczpospolita Wazów, t. III: Stawne Państwo Wielkie Księstwo Litewskie (Warszawa, 2008).

WYSŁOUCH, Seweryn. Postugi komunikacyjne w miastach W. Ks. Litewskiego na prawie magdeburskiem do potowy XVI w. (Wilno, 1936).

YANUSHKEVICH, Andrei. Vyalikaye Knyastva Litoy̆skaye i Inflyantskaya vayna 1558-1570 gg. managrafiya (Minsk, 2007).

ZAKRZEWSKI, Andrzej B. Wielkie Księstwo Litewskie (XVI-XVIII w.). Prawo - ustrój - spoteczeństwo (Warszawa, 2013).

ZAKRZEWSKI, Andrzej. Chorażowie nie tylko w parlamentaryzmie litewskim, in: Hortus bellicus. Studia z dziejów wojskowości nowożytnej. Prace ofiarowane Profesorowi Mirostawowi Nagielskiemu, ed. K. Bobiatyński, P. Gawron, K. Kossarzecki, P. Kroll, D. Milewski (Warszawa, 2017), pp. $71-8$ o.

\section{PASTOČIŲ MOKESČIO IৃVEDIMAS IR PASTOČIŲ PASLAUGŲ IŽDO VEIKLA LIETUVOS DIDŽIOJOJE KUNIGAIKŠTYSTĖJE}

Santrauka

\section{KAROL ŁOPATECKI}

Straipsnyje analizuojama veikla ir normatyviniai aktai, kurie tapo pagrindu galioti pastočių mokesčiams 1546-1578 m. laikotarpiu. Šalia aptariamas ir LDK priimtų sprendimų poveikis tokios pačios sistemos įdiegimui Lenkijoje 1564-1565 m. Tekste analizuojamas šio mokesčio pagrindimas ir taikytų taisyklių bei rinkliavų ypatybès. Pažymėtina, kad didikai priešinosi naujo mokesčio įvedimui daug labiau, nei, pavyzdžiui, keliolika kartų didesniems specialiems vienkartiniams mokesčiams.

Straipsnyje atskleidžiamos šios rinkliavos marginalizavimo priežastys, lėmusios ị LDK iždą surenkamų sumų nuolatinị mažejjimą. Pabrěžiama, kad vienintelis nuolatinis metinis mokestis LDK buvo įvestas $1588 \mathrm{~m}$. Tokia padètis tęsėsi tol, kol karalius Vladislovas IV įteisino kvartos mokestị. Dèl naujų ịplaukų potencialios metinès iždo pajamos pakilo 270o-440o zlotuc, kurių dalis buvo skiriama ir pastočių sistemai atsižvelgiant i jos teikiamas transporto paslaugas. Pastočių iždui vadovavo iždininkas ir iždo raštininkas. Jų pareiga buvo išmokèti nurodytas sumas kurjeriams, pasiuntiniams ir kitiems keliaujantiems valstybès tarnautojams. 